\title{
Conserving Environment Through Local Wisdom of Organic Vegetable Crops in West Java Indonesia
}

\author{
O.I.B. Hariyanto * \\ Akpar BSI \\ Bandung, Indonesia \\ * oda.oib@bsi.ac.id
}

\begin{abstract}
Until today, vegetable farmers still use inorganic fertilizer to fertilize the soil and chemical pesticide to eradicate pests. It is assumed to be quite practical and effective use inorganic fertilizer and chemical pesticide, are the most powerful to increase vegetables quantity. Without calculating negative impact towards environment and human health, also it gives impact towards greenhouse gasses cumulatively cause global warming. A wise solution is back in the era before 1970, in that time farmers are very depends on local wisdom. Now, vegetable cultivation based on local wisdom has been four decades old abandoned by farmers, it is assumed to be ineffective and inefficiency towards development era. The aim of study is to explore and conserve vegetables cultivation based on local wisdom to minimize the impact towards human and natural environment. Qualitative research method and ethnography approach used to analyze with this study reason and discuss about the latest actual and factual problems. Data produced is descriptive data that relates to local wisdom of Sundanese Culture in West Bandung. Agriculture based on local wisdom is not about something new, but after four decades are abandoned for farmer generation now it is something new.
\end{abstract}

Keywords-Conserving Environment; Local Wisdom, Vegetable Farmers

\section{INTRODUCTION}

In the beginning, the use of inorganic fertilizer gives positive impact to vegetable farmers. It fertilizes the soil so it improves vegetable crops of production results. But the use of sustainable inorganic fertilizer can cause the ground hardens and lowering the soil of $\mathrm{pH}$, so the soil becomes not fertile anymore and it decreases production result of vegetable crops. The use of inorganic fertilizer in long time period is always accompanied with environmental problems, both for biological fertility and physical condition of solid and also the impact to customer. That is the case for eradicating pests of vegetable crops, farmers often use pesticide, in order to vegetable crops are spared from pest attack that will damage vegetable quality. In line with business to increasing vegetable crops production, the use of pesticide as pesticides is seen to be improved from year to year. In the study of Anhar stated that the use of pesticide excessively and continuously on vegetable crops will impact to human health and living environment.
The use of chemical insecticides excessively in controlling pest will harm because direct application exposes surface of vegetable leaves. Vegetation planting period until harvest is relatively short so at the time of harvest al-lows pesticide residue is on vegetables. The study of Ameriana said the use of pesticide unwisely, it can emerge some negative impact both on human and environment. The highest of pesticide poisoning in developing countries; generally chemical pesticide can enter into human body through three paths such as: respiratory system, digestive system, and skin tissue. From some previous studies, so it can be concluded that the use of inorganic fertilizer to fertilize the soil can cause negative impact; it causes environmental pollution, soil, water and air. It is same case with the use of pesticide to pest killer will harm human health. The study of Girsang mentioned that the incidence of bad impact of using pesticide can be specified into 3 parts: Pesticide influences negatively towards human health, Pesticide influences negatively towards the quality of environment, and Pesticide can threat the existing ecosystem balance condition, spread widely by the wind and it will poison all the living things that are in the environment, and the most dangerous if pesticide settles in human food.

\section{LITERATURE REVIEW}

Based on research in 1987 from several places of vegetable cultivation in West Java and Central Java, residual levels that is contained in vegetables such as carrot, potato, cabbage, onion, tomato are known to have residues that exceed the maximum limit. Therefore, to save the environment and sustainable human life, so it needs new innovation that must be done towards cultivation of vegetable plants. The cultivation of organic vegetables is the wise case to maintain the pollution of the environment and the sustainability of a healthy human life. It is very dilemma for West Java Society as fans of raw vegetables "lalapan", but organic vegetables as environmental friendly product is felt to be very expensive, if it is compared than inorganic vegetable.

The study of [1] states that "As the most prominent is that organic product price is more expensive from conventional product, so it is needed customer behavior that is more caring because of product's content than product' price". The possible solution is back to nature, doing the ways of vegetable cultivation naturally without using inorganic fertilizer and pest killer without chemical pesticide. Now, it is the time for 
farmers in West Bandung to back understand ecofriendly agricultural governance by doing the ways that have been done in the past few decades, before farmers know inorganic fertilizer and chemical pesticide.

\section{METHOD}

In modern society, healthy lifestyle becomes trend of today, and it is one of standard quality measurement. Some of society selects to consume environmental friendly organic food product in order to keep their health, though it is expensive price. The study of Silitonga said that healthy lifestyle can be started by consuming organic vegetables; it is a vegetable produced from natural substances without using synthetic chemical material. The main objective of organic agriculture is providing agricultural products, especially food safe for human health, it does not cause harmful for farmers as producer and for society as consumer, and also it does not damage environment. The major problem gives understanding for farmers to switch environmental friendly agricultural system. Farmers' knowledge towards organic farming cultivation has not been much in demand by vegetable farmers.

Organic agricultural process is applied traditionally by using non-chemical materials. The principal if ecological health, so justice and protection are underlying in the management of organic farming. Healthy principle applies the conserving and healthy improvement of soil, plants, animals, earth, and human are united into organic agricultural, it is caused those components are connected to each other and they cannot be separated between its components. The research method used is a qualitative research method with the reason that research is conducted in a real or natural setting, and produces descriptive data. With an approach to understanding how people understand and explain and describe the life of a tribe. While the object of the research is a case study are vegetable farmers who work on farmland located in Bandung. Data collection techniques through observation, document analysis and indepth interviews, as key informants were farmers before the 1970 era. Informant voter techniques were carried out by snowball techniques (snowball sampling). They are farmers who manage traditional vegetable based cultivation (based on traditional), with an approach to local wisdom.

\section{RESULTS AND DISCUSSION}

\subsection{Condition and local potential in West Java}

West Bandung area includes into Bandung City and Cimahi City; most of area is used to agricultural cultivation which is $66.500,294$ HA. Protected area is about 50.150.928 HA, nonagricultural cultivation is about $12.159 .151 \mathrm{HA}$ and the rest is 1.768.654 HA. In the latest decades, West Bandung and North Ban-dung area get climate change temperature rise, greenhouse effect, they are assumed to play role in increasing temperature at West Bandung area that is caused by human activity. Hotel construction is on a large scale at North Bandung area causes the occurrence of decreased quality of green land, the use of inorganic fertilizer and chemical pesticide as pest eradication on farmland. According to study of [2], future's consequences towards climate change is always predicted to be more dramatic and it disturbs human life, such as threatened distribution of natural vegetation and biodiversity, erosion, and storm. Although there is no practical study, the relation of the use inorganic fertilizer and chemical pesticide toward temperature rise in Bandung City and surrounding. The visible symptoms show that it has been happened greenhouse effect which causes global warming improvement, like uncertain climate change, avalanche, flood that hit Bandung City.

Based on study of [3] states global warming that happened in the latest decades has caused climate change which most of them are indicated as environmental disaster like flood, drought, and the shifting of the rainy season. These environmental disasters are very influenced toward agricultural sector because it has high dependence on climatic conditions. In line with coordination meeting and circular letter from Regent of West Bandung to all SKPD to anticipate the occurrence of natural disaster that is caused by uncertain rainfall and the topography in West Bandung area.

The opinion and complaint from them who lived since 1970, they stated that Bandung city was fresh at that time, North West of Bandung is still covered by fog in the morning. But today many people feel that Bandung City and the surrounding is not fresh anymore like in the past. West Bandung has potential return as before which is by minimizing impact of greenhouse effect towards global warming.

\subsection{Traditional farmer}

A friendly farmer to environment is farmer who really pays attention and takes care of the environment in order not to damage physical, chemical, biological and ecological. They conduct agricultural land management by using organic fertilizer and eradicate pests without using chemical pesticide. In agricultural activity, there are three types of agricultures, first of agricultural model "natural" or natural farming that hinted natural power can control plants growth, it is not needed human intervention altogether. Second of agricultural model is "organic", human intervention is more intensive to use firm land and try to increase the result based on the principle of recycling that is done according to local conditions. 


\subsection{Local wisdom in eradicating pets}

The major problem that is always faced by vegetable farmers is pests attack in form of mushrooms, caterpillars, fruit flies and insects. Eradicating plants pests that damages vegetable crops so it makes the quality of vegetable reducing, it is not always use chemical pesticide. There is wisely ways can be done so it does not give poison to vegetable and it does not take cost, such as:

a. Snails destroy vegetable crops, to eradicate it by spreading ash from rice husks on surrounding vegetable plants, ash will put on slimy snails' body so it will hurt and finally dies. Snails can be eradicated herbally by using herbs from neem leaves, tobacco leaves, cassava leaves, noni fruit and betel nuts. Those materials contain xeronine, sterol, alizarin, glycine, sodium, caprylic acid, arginine, prokserine, quinine antin, trace elements, phenylalanine, niclos amide, magnesium terpenoid, antibacterial, arcobic, and scopeleto, so it can be herb plants and friendly biopesticide.

b. Pests of mushrooms is plant-disturbing organism which attacks to leaves vegetables, it is common appear when it is high rainfall. Biopesticide used to eradicate mushrooms by spraying tobacco or lemon water, on plants that exposed fungi.

c. Eradicating caterpillar pests on vegetable plants can use extract boiled onion skin and then sprayed with leaves. According to study of Deden, plant extract that can be used vegetable pesticide to control caterpillars is seed extract of "mahkota dewa" and the neem seeds, srikaya leaves, papaya leaves, mindi leaves.

d. Insects, sundanese is very like "lalapan" of basil leaves, basil planting on the side of vegetable crops provides a double benefit. Besides it is used as "lalapan" has efficacy as herbs medicine for human, it is also useful for insect repellent.

\section{CONCLUSION}

According to research result and discussion above, it can be concluded as. Now, farmers of vegetables cultivation in West Bandung have long switched generally to industrial agriculture system; the use of inorganic fertilizer and chemical exterminator are assumed more practical and effective. Farmer feels accustomed to and assume to be difficult to switch into vegetable cultivation based on local wisdom; it is caused by the wide of agricultural area.

Farmers are provided the understanding and the benefit technically, in the relation of vegetable cultivation based on local wisdom. Active and reliable field agricultural extension to give understanding of how importance of local wisdom in maintaining environment and human health. Make incubator pilot agricultural not only technology based on local wisdom to conserve environment but also human health 
[3] Rasmikayati, E., \& Djuwendah, E. (2015). Dampak Perubahan Iklim Terhadap Perilaku Dan Pendapatan Petani (The Impact of Climate Change to Farmers' Behavior and Revenue). Jurnal Manusia Dan Lingkungan, 22(3), 372-379.

[1] Hariyanto, O.I.B. 2018. Green Awareness and Purchase Intention for Organic Products in IOP Conference Series, Materials Science and Engineering, vol. 288, p. 12114.

[2] Gernowo, R. \& Kusworo, A. \& Arifin, Z. 2013. Co 2 Measurement of Variability and Analysis of the Impact of Peru-Climate Materials, vol. 3, no. 2, pp. $144-149$

[4] Purwanti, N.D. 2008. Biological Nitrogen tethering: Perspective and limitations, Wartazoa, vol. $18, \quad$ no. $1, \quad$ pp. $9-17$ 